\title{
What Matters in the Results of Repeated Intravenous Thrombolysis for Recurrent Ischemic Stroke?
}

\author{
Jian $\mathrm{Wu}^{\mathrm{a}}$ Qiang Huang ${ }^{\mathrm{b}}$ Qing-feng $\mathrm{Ma}^{\mathrm{c}}$ \\ ${ }^{a}$ Department of Neurology, Beijing Tsinghua Changgung Hospital, Beijing Tsinghua University, ${ }^{\mathrm{b}}$ Department \\ of Neurology, Shijingshan Teaching Hospital of Capital Medical University, Beijing Shijingshan Hospital, and \\ 'Department of Neurology, Xuanwu Hospital, Capital Medical University, Beijing, China
}

\section{Dear Sir,}

We read with interest the article by Laible et al. [1] regarding repeated thrombolysis (RT) for acute ischemic stroke (AIS). Although this study has attempted to address the efficacy and safety issue of RT, we strongly feel that one should be cautious in understanding the conclusion. Since the data of onset-to-treatment time were not collected in $33.3 \%$ cases and the sample size was also small, the conclusion cannot be considered powerful and authentic.

We conducted a systemic literature review in PubMed up to December, 2015. A total of 15 studies [1-15] involving 57 cases and 61 RTs were collected. The details are shown in the (table 1). The median age was 73 at the first event, the median time inter- val 225 days and $45.9 \%$ female. Heavier severity and worse functional outcome were observed in the RT group, but the difference of intracranial hemorrhages (ICHs) from 2 events did not reach statistical significance. More ICHs occurred in RTs with prior stroke within last 30 days than those in chronic stroke phase in a subgroup analysis $(25.0-4.9 \%, p=0.018)$. Only National Institutes of Health Stroke Scale (NIHSS) was significantly associated with a good functional outcome (OR 0.921, 95\% CI $0.857-0.990)$ and ICH (OR 1.177, 95\% CI 1.031-1.344) in the logistic regression analysis.

Our literature review indicated that baseline stroke severity was the main predictor of the functional outcome and ICH after RT, similar to the results of the first thrombolysis in AIS [16, 17]. The accumulation of disability (measured by NIHSS) in recurrent stroke could have contributed to the worse prognosis after RT. We concluded that the results of RTs were mainly associated with baseline stroke severity, and RTs with recent stroke should be more cautious. That is, the new onset severity and time interval between 2 events should be considered when assessing the benefit/risk ratio of RT treatment.

\section{Disclosure Statement}

The authors declare no conflicts of interest.

\section{KARGER}

E-Mail karger@karger.com www.karger.com/ene
(C) 2016 S. Karger AG, Basel

0014-3022/16/0754-0150\$39.50/0
Qiang Huang

Department of Neurology

No. 24 Shijingshan Street, Shijingshan District

Beijing City 100043 (China)

E-Mail drhuangqiang@foxmail.com 


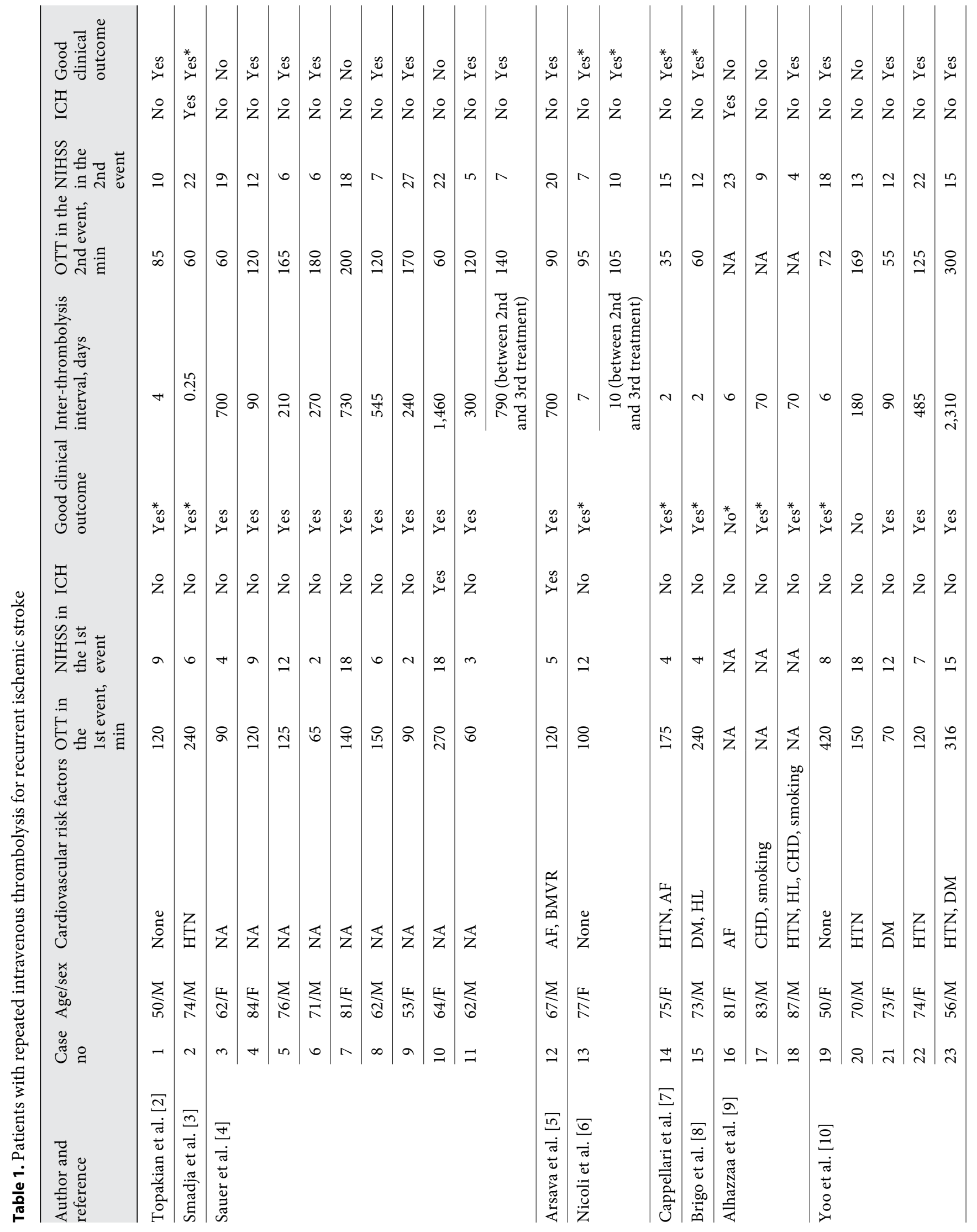




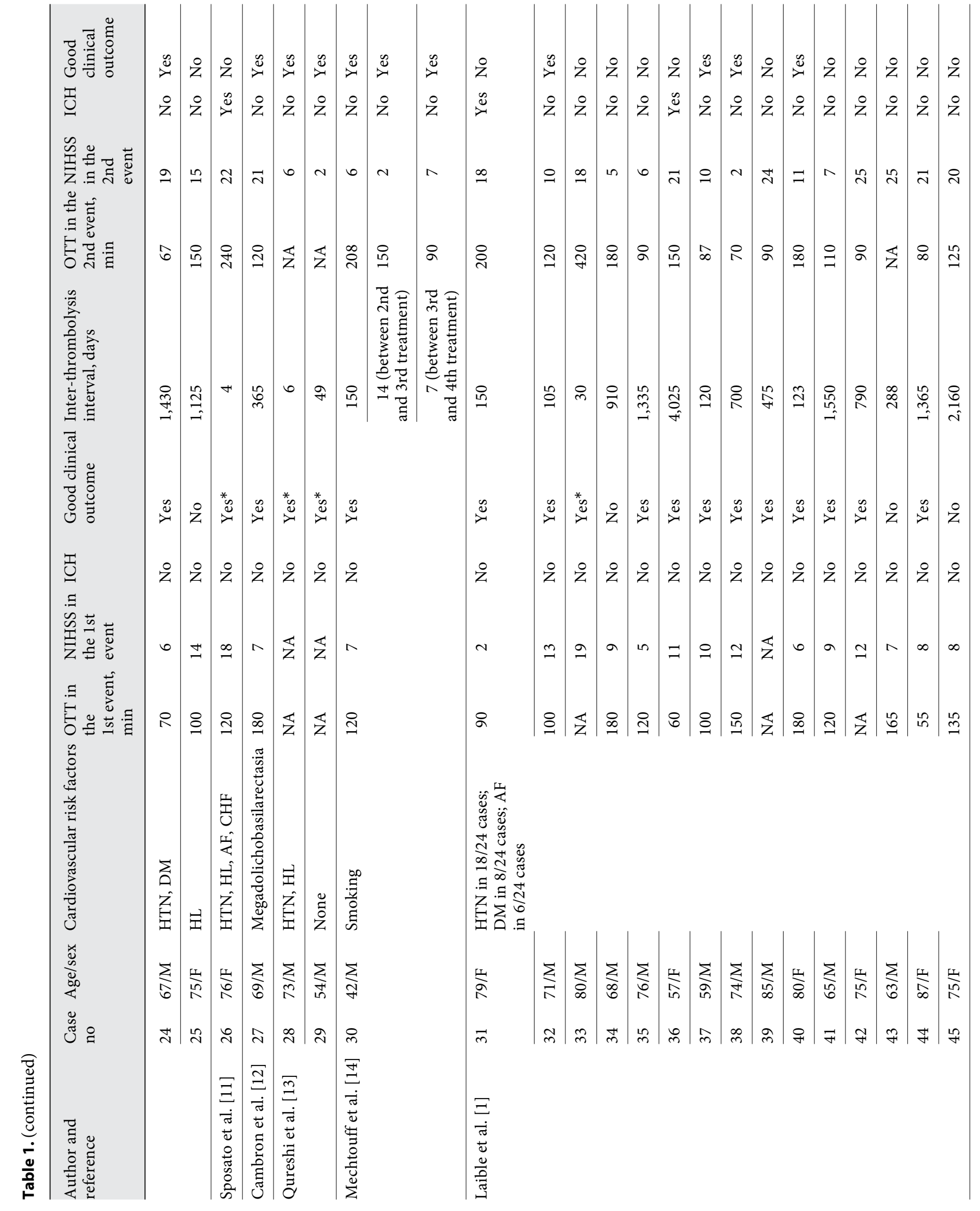




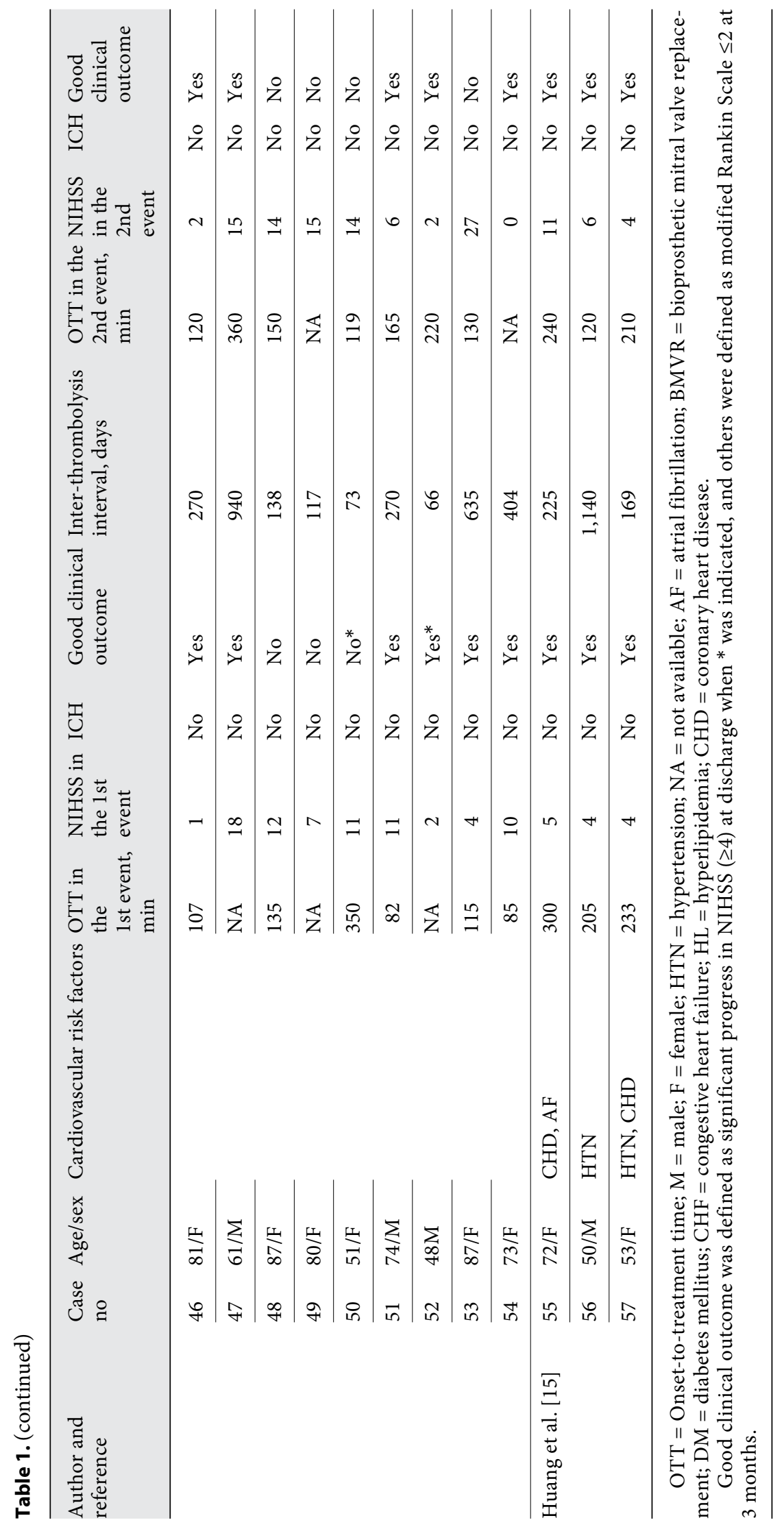




\section{References}

1 Laible M, Jenetzky E, Möhlenbruch M, Ringleb PA, Rizos T: Repeated intravenous treatment with recombinant tissue-type plasminogen activator in patients with acute ischemic stroke. Eur Neurol 2015;74:127-134.

2 Topakian R, Gruber F, Fellner FA, Haring HP, Aichner FT: Thrombolysis beyond the guidelines: two treatments in one subject within 90 hours based on a modified magnetic resonance imaging brain clock concept Stroke 2005;36:e162-e164.

3 Smadja D, Olindo S, Saint-Vil M, Chausson $\mathrm{N}$ : Sequential combination of two intravenous thrombolytics (recombinant tissue plasminogen activator/tenecteplase) in a patient with stroke and cardioembolic basilar artery occlusion. J Stroke Cerebrovasc Dis 2009; 18 68-71.

4 Sauer R, Huttner HB, Breuer L, Engelhorn T, Schellinger PD, Schwab S, Köhrmann M: Repeated thrombolysis for chronologically separated ischemic strokes: a case series. Stroke 2010;41:1829-1832.

5 Arsava EM, Topcuoglu MA: De-novo thrombolysis for recurrent stroke in a patient with prior history of thrombolysis. Blood Coagul Fibrinolysis 2010;21:605-607.

6 Nicoli F, Faivre A, Squarcioni C, Combaz X, Girard N: Repeated MR-based intravenous thrombolysis in a patient with short interval stroke recurrences. J Neuroradiol 2011;38: 256-258.
7 Cappellari M, Tomelleri G, Carletti M, Bovi P, Moretto G: Intravenous thrombolysis on early recurrent cardioembolic stroke: 'Dr Jekyll' or 'Mr Hyde'? Blood Coagul Fibrinolysis 2012;23:78-81.

8 Brigo F, Bovi T, Tomelleri G, Bovi P, Moretto G: Repeated systemic thrombolysis after early recurrent stroke: always hazardous? Can J Neurol Sci 2012;39:114-116.

9 Alhazzaa M, Sharma M, Blacquiere D, Stotts G, Hogan M, Dowlatshahi D: Thrombolysis despite recent stroke: a case series. Stroke 2013;44:1736-1738.

10 Yoo HS, Kim YD, Lee HS, Song D, Song TJ, Kim BM, Kim DJ, Kim DI, Heo JH, Nam HS: Repeated thrombolytic therapy in patients with recurrent acute ischemic stroke. J Stroke 2013;15:182-188

11 Sposato LA, Salutto V, Beratti DE, Monti P, Riccio PM, Mazia C: Adverse outcome of early recurrent ischemic stroke secondary to atrial fibrillation after repeated systemic thrombolysis. Case Rep Vasc Med 2013;2013: 371642.

12 Cambron M, Van Hooff RJ, Nieboer K, De Keyser J, Brouns R: Successful repetitive intravenous thrombolysis in a patient with recurrent brainstem infarctions due to megadolichobasilar ectasia. Jama Neurol 2013;70: 520-521.

13 Qureshi AI, Malik AA, Freese M, Thompson MJ, Khan AA, Suri MF: Readministration of intravenous alteplase in acute ischemic stroke patients: case series and systematic review. Am J Emerg Med 2015;33:307.e1-e4.
14 Mechtouff L, Ritzenthaler T, Cho TH, Derex L, Feugier P, Berthezene Y, Collet-Benzaquen D, Douek PC, Nighoghossian N: High-resolution MRI: detection of a culprit plaque after recurrent thrombolysis. J Neurol 2015;262: 2773-2775.

15 Huang Q, Ma QF, Feng J, Cheng WY, Jia JP, Song HQ, Chang H, Wu J: Factors associated with In-Hospital delay in intravenous thrombolysis for acute ischemic stroke: lessons from china. PLos One 2015;10:e0143145.

16 Emberson J, Lees KR, Lyden P, Blackwell L, Albers G, Bluhmki E, Brott T, Cohen G, Davis S, Donnan G, Grotta J, Howard G, Kaste M, Koga M, von Kummer R, Lansberg M, Lindley RI, Murray G, Olivot JM, Parsons M, Tilley B, Toni D, Toyoda K, Wahlgren N, Wardlaw J, Whiteley W, Del Zoppo GJ, Baigent C, Sandercock P, Hacke W; Stroke Thrombolysis Trialists' Collaborative Group: Effect of treatment delay, age, and stroke severity on the effects of intravenous thrombolysis with alteplase for acute ischaemic stroke: a metaanalysis of individual patient data from randomised trials. Lancet 2014;384:1929-1935.

17 Jickling GC, Liu D, Stamova B, Ander BP, Zhan X, Lu A, Sharp FR: Hemorrhagic transformation after ischemic stroke in animals and humans. J Cereb Blood Flow Metab 2014; 34:185-199. 